\title{
John Desmond Shone, Lt (Retired), RNVR, MD, FRCPC
}

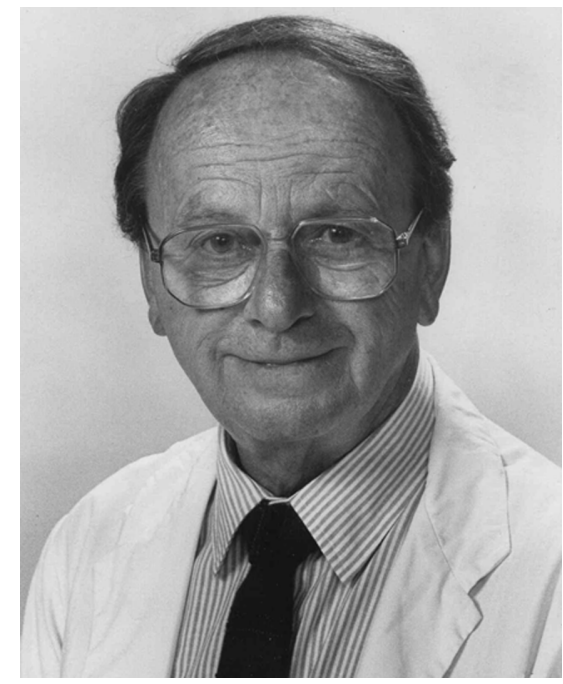

$\mathrm{W}$

HILE THE DESIGNATION OF SHONE'S syndrome will continue to survive as the eponym for patients with a peculiar constellation of anomalies involving the inflow and outflow tracts of the left ventricle, Dr John Desmond Shone, after whom these anomalies are named, died on July 12, 2002 in Bobcaygeon, Ontario, Canada after a brief illness. He leaves his wife, Jette, and their children, John, Anne and Paul.

John Desmond Shone was born in North Wales on July 4, 1924. He served from 1943 to 1946 in the Royal Navy during the 2nd World War, attaining the rank of Lieutenant. After the war, he graduated in 1953 with batchelor's degrees in Medicine and Surgery from the University of London. He then emigrated to North America in 1957, subsequently qualifying in pediatrics in 1959 in Canada, obtaining his fellowship in this topic. He practiced for a short time in Winnipeg, Manitoba, before moving to the United States of America. As he reminded me so often, perhaps the benchmark of his career was the time he spent with Dr Jesse Edwards at the University of Minnesota in the early 1960s, where he studied cardiac pathology. While studying with Jesse Edwards, he was asked by Jesse to study and characterize a series of hearts with "parachute mitral valve", supravalvar ring of the left atrium, subaortic stenosis, and coarctation of the aorta. When he discussed authorship of this paper with Jesse, Dr Edwards said to him: "John, my career is already established, but anything I can do to help you, I would like to do. You should be the first author of this paper, and it will likely make you famous." And the rest, as they say, is history. John Shone remembered the time he spent with Jesse with great affection and respect. He regarded Jesse as a wonderful teacher, mentor, and human being, recounting this story often about the birth of the "Shone" syndrome. He authored and co-authored a number of papers with Dr Edwards and his colleagues on various aspects of cardiac pathology from the early to mid 1960s.

After completing his time in Minnesota, John then moved to Toronto, spending about 18 months as a research fellow at the Toronto Hospital for Sick Children. During this time, he co-authored papers with the late John Dow Keith, the first director of the Division of Cardiology. The remainder of his career was spent in Toronto in clinical pediatric cardiology and neonatology. He was former chief of pediatrics at the Toronto East General Hospital from 1977 to 1987, remaining as a consultant there until his retirement in 1998. For more than three decades, John participated in the outpatient clinics for pediatric cardiology at the Hospital for Sick Children. He was a wonderful teacher and caregiver. With his elegant Welsh accent, and always well-attired appearance, he cut a splendid figure as the consummate consultant. Kind and gentle in demeanor, his patients revered him. He always took as much time as was needed to explain the pertinent issues to the families of his patients. He was, indeed, devoted to his patients.

I chatted with him on occasion about retirement. He considered for a while retiring in Nova Scotia, deciding eventually to live in Bobcaygeon, a beautiful area in the Kawartha region of Ontario. A religious man, he became People's Warden at Christ Church Anglican in Bobcaygeon. John will be deeply missed by his family, colleagues, friends and patients. As we continue to use the designation "Shone's syndrome", all caring for patients with congenital heart disease acknowledge his contribution to our wonderful specialty. 